\title{
Abordagem Freudo-Frankfurtiana, Pesquisa- Ação e Socioanálise: Uma proposta alternativa para os Estudos Organizacionais
}

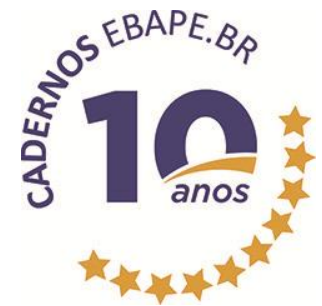

\section{Freudo-Frankfurtian approach, Action Research, and Socioanalysis: An alternative proposal for Organizational Studies}

\author{
Ana Paula Paes de Paula ${ }^{1}$
}

\begin{abstract}
Resumo
Este artigo propõe uma reflexão acerca da abordagem freudo-frankfurtiana e a estratégia de pesquisa que dela deriva, articulando a metodologia de pesquisa-ação à socioanálise de René Lourau. A abordagem freudo-frankfurtiana que apresentamos realiza uma reconstrução epistemológica, evidenciando a proximidade entre a epistemologia frankfurtiana e a epistemologia freudiana, para elaborar um suporte teórico-analítico que instrui essa metodologia. Argumentamos que tal abordagem e metodologia propiciariam uma conjunção entre teoria e práxis, uma vez que promovem uma profunda interação entre pesquisador e pesquisados, além de ter a emancipação como um dos valores que norteiam a investigação. Nosso objetivo é buscar um saber e uma construção de conhecimento para os estudos organizacionais orientados pelo interesse emancipatório que seja tecnicamente aplicável e guie a atividade prática/comunicativa. Com o propósito de apresentar esta proposta alternativa para os estudos organizacionais, neste artigo, primeiramente apresentamos e discutimos a abordagem freudo-frankfurtiana, realizando uma reconstrução epistemológica. Na segunda parte, sistematizamos um suporte teórico-analítico a partir do qual elaboramos a estratégia de pesquisa anteriormente mencionada. Em seguida, apresentamos nossas considerações finais, concluindo que apontamos saídas para a pesquisa organizacional que privilegiam a prática e a emancipação, pois recomendamos que as investigações tenham um objetivo de conhecimento, mas, também, um objetivo prático, de modo que o analista organizacional pactue com o grupo ou organização abordados, sem deixar de incentivar sua autonomia, indicando quais são as metas coletivas da investigação, qual é o plano de ação a ser implementado e, ainda, realizando uma avaliação coletiva dos resultados.
\end{abstract}

Palavras-chave: Estudos Organizacionais. Epistemologia Crítica. Pesquisa-ação. Socioanálise. Psicanálise.

\begin{abstract}
This article proposes a reflection on the Freudo-Frankfurtian approach and the research strategy derived from it, linking the methodology of action research to René Lourau's socioanalysis. The Freudo-Frankfurtian approach we present undertakes an epistemological reconstruction, showing the closeness between Frankfurtian epistemology and Freudian epistemology, to prepare a theoretical and analytical support that instructs this methodology. We argue that such approach and methodology could enable a conjunction between theory and praxis, since they promote a deep interaction between researcher and researched subjects, besides having emancipation among the values guiding investigation. Our purpose is seeking some knowledge and some knowledge construction for the organizational studies guided by the emancipatory interest, which is technically applicable and drives the practical/communicative activity. In order to present this alternative proposal for organizational studies, in this article, first, we present and discuss the Freudo-Frankfurtian approach, conducting an epistemological reconstruction. In the second part, we systematize a theoretical and analytical
\end{abstract}

Artigo submetido em 13 de abril de 2013 e aceito para publicação em 09 de setembro de 2013.

${ }^{1}$ Doutora em Ciências Sociais pelo Instituto de Filosofia e Ciências Humanas/UNICAMP; Professora Titular da Universidade Federal de Minas Gerais. Endereço: Av. Antônio Carlos, 6627 - sala 4033 - FACE-UFMG, Pampulha, CEP 31270-010, Belo Horizonte - MG, Brasil. E-mail appaula@face.ufmg.br 
support through which we prepare the research strategy mentioned above. Then, we present our final remarks, concluding that we pointed out alternatives for organizational research that privilege practice and emancipation, since we recommend that investigations have a knowledge purpose, but also a practical purpose, so that the organizational analyst agrees with the group or organization approached, while encouraging its independence, indicating which are the collective research goals, what is the action plan to be deployed, and, also, making a collective assessment of results.

Keywords: Organizational Studies. Critical Epistemology. Action Research. Socioanalysis. Psychoanalysis.

\section{Introdução}

Enquanto ciência social aplicada, a expectativa que se tem em relação à Administração é que ela produza conhecimentos técnicos, que possam ser utilizados em situações reais. No entanto, a área tem sido constantemente criticada por se dedicar a pesquisas que não têm relevância para as organizações. Isto se agrava, quando se consideram investigações que utilizam a epistemologia crítica, que utiliza referenciais teóricos da Escola de Frankfurt e neomarxistas, pois em geral estes trabalhos são tomados como puramente teóricos e afastados da prática, além de realizarem críticas sem apontar saídas.

O debate em geral se dirige para a falsa dicotomia entre teoria e práxis, uma vez que não podemos dizer que não há teoria sem prática e vice-versa. Isto porque a teoria representa uma tentativa sistematizada de explicar e compreender a realidade: a partir dela são criados conceitos por meio dos quais é possível apreender o real. O empirismo científico nada mais é do que a observação mediada por teorias e gera um saber que é utilizado para a ação prática e para a produção teórica. Por outro lado, a própria teorização também é práxis, pois, sem uma avaliação crítica do nosso mundo, não é possível transformá-lo.

A transformação por meio das práticas significa que o pesquisador na área de administração, comprometido com uma epistemologia crítica, deveria estar implicado nos processos que pretende estudar. Para isto, a técnica de pesquisa a ser utilizada é a observação associada à intervenção na realidade estudada, de modo que não se trataria mais de uma "análise do processo", mas de uma "análise em processo". O foco não é só análise, mas também intervenção, de modo que, além de reconstruir aportes teóricos, o pesquisador deveria atuar para modificar a realidade estudada. Considerando que o cerne das investigações de caráter crítico é a transformação social, este tipo de pesquisa poderia trazer grandes avanços para os estudos organizacionais críticos.

É na esteira dessa discussão que este artigo propõe uma reflexão acerca de uma abordagem freudofrankfurtiana e uma estratégia de pesquisa que dela deriva, articulando a metodologia de pesquisa-ação e a socioanálise de René Lourau. A abordagem freudo-frankfurtiana que apresentamos é baseada em uma reconstrução epistemológica, que evidencia a proximidade entre a epistemologia frankfurtiana e a epistemologia freudiana, criando condições para a elaboração de um suporte teórico-analítico que instrui esta metodologia. Argumentamos que tal abordagem e metodologia propiciariam uma conjunção entre teoria e práxis, uma vez que realizam uma profunda interação entre pesquisador e pesquisados, além de ter a emancipação como um dos valores que norteiam a investigação. Além disso, nosso objetivo é buscar um saber e uma construção de conhecimento para os estudos organizacionais orientados pelo interesse emancipatório, que seja tecnicamente aplicável e guie a atividade prática/comunicativa. Com o propósito de apresentar esta proposta alternativa para os estudos organizacionais, neste artigo primeiramente apresentamos e discutimos a abordagem freudo-frankfurtiana. Na segunda parte, sistematizamos um suporte teórico-analítico a partir do qual elaboramos a estratégia de pesquisa anteriormente mencionada. Em seguida, realizamos as considerações finais. 


\section{Abordagem Freudo-Frankfurtiana}

Nesta seção, realizamos uma reconstrução epistemológica a fim de discutir os elementos que fundamentarão o suporte teórico-analítico da abordagem freudo-frankfurtiana. Podemos afirmar que a reconstrução epistemológica é o método que utilizamos para compor esta abordagem. Segundo Hill (1984), uma investigação epistemológica frequentemente requer uma "escavação" e reconstrução de "elementos perdidos" de um sistema de conhecimento. É exatamente isto que realizamos ao buscar um entrelaçamento entre a epistemologia frankfurtiana e a epistemologia freudiana, evidenciando as relações que existem entre elas. Para isto, recorremos aos textos frankfurtianos e freudianos, aos escritos de epistemólogos freudianos como Japiassu (1998) e Assoun (1983) e também ao trabalho de Rouanet (1985; 2001) que faz uma recuperação rigorosa e sólida das articulações entre estas epistemologias.

Adeptos da Escola de Frankfurt são frequentemente acusados de realizarem a crítica pela crítica, sem nenhuma intenção técnica ou prática. Para se fazer uma ciência crítica, é preciso transcender o domínio da filosofia para chegar à ciência, e o caminho para isso é o método, que é familiar às ciências empíricoanalíticas e hermenêuticas ${ }^{2}$. O que precisa ficar claro é que o uso do método não implica afastamento dos interesses emancipatórios se esses são colocados como norte da pesquisa: Adorno comprovou isso com os estudos que realizou sobre a personalidade autoritária, quando recorreu aos métodos quantitativos (ADORNO, FRENKEL-BRUNSWIK e LEVINSON et al., 1950; 1993).

Michel Löwy (1998) faz uma análise aguda dessa limitação da Escola de Frankfurt, que a afastou das suas intenções no campo da práxis. Para o autor, a razão crítica e a essência humana são o "ponto arquimédico" que representa o interesse emancipatório, que em geral conflita com o interesse técnico ligado à razão instrumental. A Escola de Frankfurt não oferece "alavanca para erguer o mundo", pois está no domínio da filosofia e não da ciência e da técnica, às quais dirige sua crítica na forma da oposição entre o positivismo e a dialética. Na filosofia, o embate se dá entre a filosofia positiva, que sustenta as ciências empírico-analíticas e a filosofia negativa, que embasa as ciências críticas, ou entre a lógica formal e a lógica dialética. A dicotomia realiza um divórcio entre o mundo material e o mundo das ideias.

Ora, a ciência crítica deveria ser o caminho de reconciliação. A Escola de Frankfurt, enquanto fonte epistemológica, oferece pistas, mas é preciso realizar um esforço para passar da filosofia à ciência. Não é casual que os frankfurtianos tenham recorrido insistentemente à psicanálise freudiana em seus estudos. Na nossa visão, a psicanálise é a ponte por meio da qual a filosofia negativa exercida pelos frankfurtianos encontra o caminho da ciência, sendo que o método psicanalítico se coloca como uma "alavanca", como um suporte para conectar a filosofia ao mundo material. É por esse motivo que optamos por realizar uma reconstrução epistemológica, aproximando a epistemologia crítica frankfurtiana e a epistemologia freudiana, para em seguida desembocar em caminhos metodológicos para a pesquisa e a intervenção nas organizações, que são mediados pelo método psicanalítico.

Habermas $(1968 ; 1982$, p. 233) oferece essa pista, ao afirmar que a psicanálise é "[...] relevante como o único exemplo disponível de uma ciência que reivindica metodicamente o exercício autorreflexivo." Freud teria entendido a sociologia como uma psicologia aplicada, trazendo as questões da psicanálise para o campo da teoria social. A superação da dominação na sociedade passaria pela autorreflexão do sujeito, além de uma autorreflexão do próprio conhecimento, tendo em vista uma compreensão aprofundada das estruturas do trabalho, da linguagem e do poder. Nesse processo não há sentido em separar os interesses cognitivos (técnico, prático e emancipatório) apontados por Habermas (1968; 1982), como se cada um deles estivesse restrito a determinados domínios, pois tanto a dominação quanto a libertação perpassam os três interesses.

${ }^{2}$ Seguindo a linha de pensamento de Habermas (1968; 1982) temos: 1) as ciências empírico-analíticas, também conhecidas como nomológicas, que são dirigidas pelo interesse técnico e geram conhecimento para possibilitar a predição e o controle dos fatos sociais; 2) as ciências hermenêuticas, que são orientadas pelo interesse prático, que buscam a compreensão social por meio da comunicação e interpretação; 3) as ciências críticas, que são motivadas pelo interesse emancipatório, voltando-se para a transformação social. 
Por outro lado, a busca da autoconservação humana não pode ser compreendida como uma satisfação imediata das necessidades, mas como a base na qual estão assentadas as condições de funcionamento do trabalho e da interação. Dessa forma, as teorias científicas deveriam se desdobrar em um saber tecnicamente aplicável, mas também em um saber para orientar a atividade prática, ambos sendo orientados pelo interesse emancipatório. É neste ponto que pretendemos chegar, mas antes será necessário fazer uma reconstrução epistemológica a partir da epistemologia crítica frankfurtiana e da epistemologia freudiana para constituir um suporte teórico-analítico para a abordagem freudo-frankfurtiana.

Em primeiro lugar, é preciso considerar que Adorno (1974; 1999), em sua controvérsia com Popper, não opõe o positivismo à crítica, mas o positivismo à dialética. Horkheimer (1937; 1980), por sua vez, fundamenta sua discussão em Teoria Tradicional e Teoria Crítica em uma teoria dialética de sociedade Então, por que a Escola de Frankfurt ficou caracterizada como defensora da teoria crítica e não da teoria dialética? A questão é que a epistemologia crítica frankfurtiana se fundamenta em uma lógica e explicação do mundo dialéticas, mas uma forma de ver o mundo crítica, entendendo como crítica a emancipação. Tanto para os frankfurtianos quanto para Freud, dialética e crítica podem ser tratadas como sinônimos, como veremos mais adiante.

Em contraposição, a teoria dialética de sociedade considera que os fatos sociais são determinações quem não têm origem em elementos puramente lógicos ou metodológicos, pois só podem ser compreendidos em conexão com processos sociais reais, que não se fundamentam exclusivamente por ponderações lógicas, mas precisamente nas contradições, ou seja, na dialética: essa é sua forma de explicar o mundo. Para a teoria dialética de sociedade, o trabalho teórico sem dúvida ocorre dentro da ordem da realidade existente, mas a ciência não é vista apenas de um ponto de vista pragmático, como um trabalho profissional socialmente útil. Isso porque para a teoria dialética de sociedade importa que a ciência esteja orientada para a emancipação, tendo como meta a transformação do todo: essa é sua forma de ver o mundo. Como na história da filosofia, na acepção kantiana, a crítica é a capacidade de sair do estado de menoridade e se emancipar, a teoria dialética de sociedade, herdeira que é do idealismo alemão, ficou conhecida como teoria crítica, em oposição ao positivismo. Além disso, o entendimento do que é a dialética para os frankfurtianos os levam a considerála como sinônimo de crítica, pois ela seria uma operação que leva à emancipação.

Adorno (1974; 1999) sustenta que a verdade da realidade social é que ela é plena em contradições e seu dinamismo não admite certezas. Logo, a objetividade pretendida pelos positivistas seria falsa, pois suas certezas não passam de abstrações diante do que de fato é a realidade social. Por ser falsa, podemos dizer que é ideológica. Assim, para Adorno, buscando serem objetivistas, os positivistas acabam paradoxalmente sendo subjetivistas, afastando-se de seu propósito inicial. Ironicamente seriam os dialéticos que, renunciando à pretensão de objetividade, os que mais se aproximam do objetivismo, pois apresentam a existência de contradições que melhor refletem a realidade social. A dialética encara a sociedade de um modo mais micrológico que o positivismo. $O$ singular para os dialéticos não é tomado apressadamente, pois o fenômeno singular encerra em si toda a sociedade: a micrologia e a mediação são mecanismos para alcançar a totalidade. Por outro lado, conceitos como o de hipótese e testabilidade não podem ser simplesmente transferidos das ciências naturais para as ciências sociais: o postulado positivista da verificação precisa ser substituído pela "possibilidade de confirmação". Os fatos neste caso estão sujeitos a uma "possível confirmação" a partir de situações do passado e do futuro, de modo que a objetividade científica deriva da explicação que melhor reflete a realidade social em seu dinamismo e contradições. Por esse motivo, podemos dizer que o caráter especulativo das proposições dos dialéticos é uma autorreflexão crítica do entendimento e não mera futilidade de opiniões sem confrontação com a realidade.

Estas características da epistemologia frankfurtiana também aparecem na epistemologia freudiana, pois, de acordo com Japiassu (1998), o modelo de psiquismo de Freud tem todas as características de um modelo científico, porém a realidade ou a verdade do psiquismo não é suscetível de verificação, uma vez que o imediato vivido nos é inacessível. Tudo que o psicanalista tem a sua disposição é o relato do seu paciente, cujo sentido só é apreensível por meio de uma interpretação que seja aceita por este paciente e que ainda 
esbarra na dificuldade de haver a hipótese de uma interpretação negada devido à resistência do próprio paciente, condição que inclusive é muito comum nas neuroses ${ }^{3}$. De acordo com Japiassu (1998), diante de um saber que não tem condições de ser verificado ou falsificado objetivamente, o que temos são os seguintes critérios: a verossimilhança da interpretação e sua possibilidade de integrar os fenômenos a serem explicados. Ou seja, as interpretações são colocadas e sendo aceitas, ou capazes de vencer as resistências do paciente, podemos dizer que são válidas: a interpretação nunca tem o estatuto de uma verdade definitiva, mas uma interpretação que não faz sentido em um contexto não está necessariamente errada, pois pode fazer sentido em outro contexto, com adaptações.

Para Assoun (1983), o fato de a psicanálise freudiana não ser susceptível de verificação e validação empírica é justamente aquilo que a diferencia enquanto epistemologia, pois aponta para nova noção de ciência. O fato de a psicanálise ser um saber fronteiriço faz dela um exemplo importante para elucidar a questão da cientificidade das ciências humanas, pois quando tratamos de fenômenos sociais, temos também fenômenos que oscilam entre o naturalismo e a hermenêutica, entre o físico e o metafísico, até porque temos o homem e sua psique envolvidos. Assim, o problema do estatuto científico da psicanálise e o das ciências humanas caminham lado a lado. Dessa forma, argumentamos que a epistemologia crítica frankfurtiana e a epistemologia freudiana são bases de um outro tipo de ciência, que se expressa na abordagem freudofrankfurtiana que estamos aqui constituindo.

O fato é que a psicanálise e as ciências sociais não podem funcionar por meio do mesmo tipo de objetividade e causalidade do positivismo, pois são portadoras de inegáveis especificidades. As ciências sociais atualmente oscilam entre dois modelos: o positivista (explicativo) e o interpretativo (compreensivo) (DOSSE, 2003). O modelo interpretativo tem suas inter-relações com a psicanálise e inclusive há um esforço dos hermeneutas (ASSOUN, 1983) para evidenciar que a interpretação é uma variante da explicação. No entanto, diante da epistemologia crítica frankfurtiana, não podemos deixar de lado a perspectiva dialética, que não se esgota nas relações de causalidade, pois tem como ingredientes principais as relações de contraditoriedade, que também têm uma forte presença na psicanálise. Em outras palavras, não basta explicar, interpretar e compreender, pois a epistemologia crítica frankfurtiana envolve principalmente a dialética, ou seja, é preciso admitir, como muitas vezes Freud faz, que os fenômenos são isto e ao mesmo tempo também aquilo.

Por outro lado, a autonomia da identidade epistemológica freudiana transparece, segundo Assoun (1983), na técnica utilizada por Freud em sua ciência, que é heurística, pois ele não utiliza a perspectiva experimental, ou seja, não recorre às experiências in vivo: verificar a teoria para Freud é revelar materialmente o vestígio na estrutura que a confirma. Em outras palavras, Freud privilegiava o fato isolado - que seria o vestígio em detrimento das estatísticas generalizantes, sendo que preferia a observação à experimentação. Além disso, segundo Rouanet (1985), o ineditismo da epistemologia freudiana está na consideração do erro como parte do processo de conhecimento, que imbrica sabido e não sabido e consciência e não consciência. Além disso, para além da hermenêutica, a epistemologia freudiana inclui uma forma de pensar que é dialética: partindo de um vestígio, um fato isolado, um erro lógico ou psicológico, uma contradição, ela percorre a cadeia associativa cognitiva até encontrar onde estão as incoerências e atingir uma interpretação que seja uma explicação para isso, ou seja, encontrar um esclarecimento, que é a tônica da emancipação. Importante notar que a dialética e a crítica se entrelaçam: a forma de pensar, a lógica dialética, é a operação que concretiza a visão de mundo, a emancipação. A operação pode ser chamada de crítica, pois é em um só gesto, pensamento e ação, no sentido da práxis: daí dialética e crítica serem tomadas como sinônimos.

3 A neurose é caracterizada por Freud (1905; 1906; 1996) por meio do fenômeno do recalcamento: as representações consideradas intoleráveis pelo sujeito são retidas no inconsciente, mas o afeto fica livre, ligando-se a representações distintas das originárias e manifestando-se na forma do sintoma, que nada mais é que uma forma desviada de atividade sexual. Assim, a pulsão que não se satisfaz como desejava, devido ao recalque, encontra outras vias de satisfação, ainda que essas sejam patológicas. Surgem dessa forma as psiconeuroses: fobia, histeria e neurose obsessiva. 
Um exame acurado das bases destes sistemas de conhecimento demonstra que há uma evidente articulação entre a epistemologia crítica frankfurtiana e a epistemologia freudiana. De acordo com Rouanet (2001, p. 11), “[...] o freudismo não é, para a Escola de Frankfurt, uma influência: é uma interioridade constitutiva, que habita seu corpo teórico e permite à teoria crítica pensar seu objeto, pensar-se a si mesma e pensar o próprio freudismo enquanto momento da cultura." Em outras palavras, o freudismo está incrustado no pensamento da Escola de Franfurt. A presença de Freud se faz sentir em cada um dos momentos da reflexão frankfurtiana - a crítica da cultura, a teoria da personalidade e o estatuto do conhecimento - mas funciona de forma distinta em cada um dos autores da Escola, caminhando da síntese freudo-marxista dos anos 1920 e 1930 para a epistemologia dialógica de Habermas.

Para Rouanet (2001), a Escola de Frankfurt teria notado que a classe proletária mudou de status e passou a ter acesso às benesses do mercado de consumo, de modo que se torna presa da cultura dominante: "No passado a falsa consciência levava à aceitação do sofrimento em nome de uma ideologia legitimadora desse sofrimento; hoje a falsa consciência consiste em obliterar a própria noção de sofrimento." (ROUANET, 2001, p. 73) Assim, quando a ideologia se confunde com a realidade, ou seja, o sofrimento com a dominação cede lugar ao prazer da fruição com o consumo, a crítica passa a ser da cultura. Isso recoloca a psicanálise no centro do trabalho crítico, pois ela complementa a crítica marxista.

A epistemologia freudiana está incrustada na epistemologia crítica frankfurtiana, sendo ambas dialéticas enquanto forma de pensamento e críticas na sua forma de ver o mundo, considerando que dialética e crítica são uma só operação, pois é a dialética que abre o caminho para a emancipação. Por outro lado, ambas também estão enraizadas no solo do humanismo. De acordo com Rouanet (2001, p. 99), o freudismo contribui para a formação da teoria crítica e proporciona elementos para sua crítica da cultura: as afinidades eletivas entre as duas formas de reflexão são tamanhas, que é possível dizer que "[...] a Escola de Frankfurt teria absorvido do freudismo não somente certos instrumentos de análise, como, até certo ponto, o próprio 'estilo' que dá contornos específicos à teoria crítica". Os pontos de cruzamento entre epistemologia crítica e epistemologia freudiana envolvem questões epistemológicas, metodológicas e filosóficas.

No plano epistemológico, a intersecção entre o freudismo e a teoria crítica se revela na hostilidade que ambos cultivam em relação ao positivismo. Rouanet (2001) reconhece que os detratores de Freud tentaram propagar a tese de que seu pensamento seria uma continuação do cientificismo do século XIX, que tem de verdadeira o fato de Freud ver na psicanálise uma ciência natural. No entanto, se ater a este ponto é uma simplificação, pois "[...] toda a démarche psicanalítica é uma interminável refutação, em sua teoria e sua prática, da razão positivista. Ela se opõe, ponto por ponto, à descrição feita por Horkheimer da teoria tradicional." (ROUANET, 2001, p. 101).

No plano metodológico, tanto teoria crítica quanto psicanálise procedem de acordo com uma crítica imanente de seu objeto (ROUANET, 2001). A crítica transcendente se opõe à crítica imanente, pois não está interessada, por exemplo, no conteúdo de um objeto da cultura (obra de arte ou reflexão filosófica, por exemplo), mas apenas na sua localização no espaço das superestruturas (cultura e ideologia). A crítica transcendente seria uma espécie de pensamento topológico que situa o objeto, mas não capta sua essência, enquanto que a crítica imanente mergulha no objeto, procurando examinar seu conteúdo de verdade, tendo em vista sua interação com o todo. O particular seria a via através da qual a crítica consegue aceder ao todo. A crítica imanente é dialética, pois compreende que precisa se relativizar e buscar as contradições, pois ela própria, apenas como mergulho no objeto, é insuficiente.

A psicanálise é uma manifestação exemplar da crítica imanente, pois ao pensamento topológico de seus antecessores, para quem o sonho, o ato falho, o sintoma e a fantasia nada significam, Freud opõe a descoberta de que são dotadas de uma coerência interna, sendo, portanto, verdadeiras, independentemente da irracionalidade aparente de seu conteúdo manifesto. Um sonho não seria assim um tecido de ilusões, mas a via real que possibilita o acesso ao inconsciente. Um chiste e um ato falho também são formações do inconsciente. Todas essas formações do inconsciente podem ser desvendadas como conteúdo que contém mentiras e verdades, por meio da psicanálise, com o uso do método da associação livre e a interpretação. 
Assim, há um paralelismo entre a hermenêutica freudiana e a crítica imanente frankfurtiana: o método consiste em "[...] levar tão a sério o particular - mesmo o mais insignificante - que este acabe falando, e nesta fala revele aquilo que o transcende." (ROUANET, 2001, p. 107)

No plano filosófico, o ponto de cruzamento entre a psicanálise e a teoria crítica é a questão da não identidade. Esse postulado tem capital importância na teoria crítica e em Freud assume sua forma mais inflexível: trata-se da tese da impossível reconciliação entre os interesses do indivíduo e os da civilização. Emerge assim uma dialética sem síntese, pois, no plano terapêutico, Freud reconhece que não há possibilidade de cura integral e, no plano sociológico, condena o indivíduo socializado à renúncia e à repressão. O indivíduo não pode sobreviver no estado de natureza, mas não pode ser feliz no estado social: esta é a chave do mal-estar na civilização (FREUD, 1929; 1930; 1996). Assim, nem o freudismo e nem a teoria crítica fazem promessas para a felicidade humana, mas ambos partilham de um modesto otimismo, pois afirmam que "[...] o homem não é livre; mas pode tornar-se livre. Não é racional; mas pode tornar-se racional.” (ROUANET, 2001, p. 112).

Em síntese, a teoria crítica tem em comum com a psicanálise um pressuposto epistemológico (a recusa do positivismo), uma metodologia (a crítica imanente) e um postulado filosófico (o princípio da não identidade). Em outras palavras, nos arriscamos a afirmar que um entendimento amplo da epistemologia crítica frankfurtiana não é possível sem um conhecimento aprofundado da epistemologia freudiana. Ambas epistemologias não supõem somente a descoberta do existente, mas do potencial e das tendências que habitam o sujeito. Trata-se de uma estratégia teórica que privilegia o particular, recusando sua dissolução em "grandes sínteses" e tomando posição em favor da crítica imanente, recusando totalizações em nome do princípio da não identidade, ou, seja, recusando a assimilação irrefletida do sujeito à realidade em que este vive.

O percurso realizado, que mostra o entrelaçamento dessas epistemologias, constitui parte da reconstrução epistemológica elaborada para chegar ao suporte teórico-analítico do que estamos chamando de abordagem freudo-frankfurtiana, que é consistente com a teoria dialética que sustenta que os fenômenos são "isto" e "aquilo" ao mesmo tempo. A seguir, aprofundaremos algumas de suas características, tornando-a ainda mais específica, uma vez que não pretendemos perder de vista que estamos em busca de uma abordagem freudofrankfurtiana para encontrar um saber para os estudos organizacionais orientado pelo interesse emancipatório, que seja tecnicamente aplicável e guie a atividade prática/comunicativa. E foi no pensamento de Habermas, que sofreu influência dos filósofos da Escola de Frankfurt de primeira geração, que encontramos os fundamentos para uma autorreflexão coletiva, que é essencial para os propósitos anteriormente enunciados.

Continuaremos a utilizar Rouanet (2001) como a principal referência, pois, além de ser o principal analista da articulação destas epistemologias, é um comentador competente sobre o pensamento de Habermas, de modo que suas elaborações nos ajudaram a sintetizar nossa argumentação e a torná-la mais clara. Rouanet (2001) reconhece que a princípio Habermas pode parecer desconcertante, pois declara-se de um lado como um "funcionalista historicamente orientado" e de outro como "partidário do materialismo histórico". No entanto, apesar de passar a impressão de um sincretismo extremo, o pensamento crítico é que se destaca em suas elaborações, pois, como seus predecessores, sustenta a ideia de uma razão emancipatória e denuncia o positivismo. Habermas não pretende abandonar os postulados da teoria crítica, mas dar-lhes maior plausibilidade e da mesma maneira que em outros autores da Escola de Frankfurt, como já foi possível constatar, o freudismo é constitutivo de seu pensamento. É o freudismo que o ajuda a manter a articulação entre o saber existente e o projeto de um novo saber. Além disso, também estão enraizadas no freudismo tanto sua defesa de um processo de autorreflexão individual e coletiva como forma de tomada de consciência, quanto a constatação da importância da existência de uma comunicação livre de opressão.

Para a compreensão das proposições de Habermas é fundamental conhecer o que ele considera esfera da ação instrumental e esfera da ação comunicativa, conceitos que foram aprofundados por ele em Teoria da Ação Comunicativa (HABERMAS, 1981; 2010). De acordo com Roaunet (2001, p. 260). 
A esfera da ação instrumental, ou trabalho, é regida por regras técnicas, baseadas num saber empírico, e implica em prognoses sobre acontecimentos observáveis, com vistas a assegurar o controle sobre a natureza, através da correta organização de meios. A esfera da ação comunicativa, ou interação, é estruturada segundo normas válidas e obrigatórias, que definem expectativas recíprocas de comportamento, formuladas numa linguagem compreendida pelos atores, isto é, num contexto simbolicamente mediatizado, e reconhecidas por pelos menos dois atores.

Habermas associa à esfera da ação instrumental, as ciências empírico-analíticas e à esfera da ação comunicativa, as ciências hermenêuticas. Tais ciências se constituem a partir dos interesses cognitivos técnico e prático, respectivamente, que orientam e estão enraizados nas condições de reprodução e autoconstituição da espécie humana: o trabalho e a interação. Tais interesses fazem uma mediação entre teoria e prática, de modo que todo saber está incrustado na técnica ou na práxis. O problema do positivismo é ignorar isso, rompendo a conexão entre teoria e vida: é essa conexão que Habermas $(1968 ; 1982)$ tenta restabelecer a partir da teoria crítica, pois a ideologia cientificista não cessa de converter as questões práticas, ou comunicativas, em questões técnicas. Para revelar a conexão entre o conhecimento e o interesse, Habermas afirma que as teorias correspondentes ao interesse são as disciplinas críticas (a psicanálise e a crítica da ideologia), que vão além de uma mera descrição de fatos e formulação de regularidades. Essas teorias se estabelecem em um quadro metodológico, cuja validade das proposições derivam do interesse emancipatório, que é a autorreflexão, capaz de colocar em questão a ilusão objetivista e estabelecer uma possibilidade de livre comunicação entre os homens.

De acordo com Rouanet (2001), Habermas concorda com Marcuse em relação a considerar a ciência e a técnica não somente como forças produtivas, mas principalmente como ideologia. O Estado contemporâneo não vem realizando mais decisões políticas (práticas/comunicativas), mas principalmente decisões técnicas, que por estarem radicadas na objetividade seriam invulneráveis à crítica. Nesse contexto, o homem passa a auto-objetivar-se na perspectiva da ação instrumental e do comportamento adaptativo. A crítica da ciência e da cultura habermasiana e frankfurtiana então se articulam: a práxis se anula diante do comportamento condicionado e é absorvida pela techné. A consciência tecnocrática exclui do horizonte social as questões práticas (comunicativas) e o positivismo exclui do horizonte cognitivo as normas e valores, uma vez que as proposições descritivas são empiricamente controláveis, enquanto as proposições normativas não. As proposições normativas foram condenadas à inverificabilidade e à contingência da mera opinião, mas a teoria da ação comunicativa veio para tentar corrigir isso.

A ação comunicativa se baseia em uma intersubjetividade linguisticamente mediatizada, na qual o que interessa não é a sentença, as frases proferidas em si, mas o enunciado, que é um ato linguístico, ou seja, a conexão dessas sentenças com os contextos de ação. A relação interativa normal entre dois ou mais atores produz atos linguísticos (enunciados), em torno dos quais se há um consenso tácito que tem quatro expectativas de validade: o enunciado é compreensível, o conteúdo proposicional é verdadeiro, o locutor é veraz e agiu corretamente em seu ato linguístico e a norma implícita é justa. Em uma ação comunicativa, essas expectativas de validade não são contestadas. Quando ocorre uma perturbação delas, são necessários mecanismos específicos para reestabelecer o consenso. Para Habermas, a verdade é uma expectativa de validade que se revela no curso de um processo de argumentação discursiva, de modo que "[...] uma afirmação verdadeira é aquela em torno da qual se produz um consenso razoável, no contexto de um discurso teórico, e uma recomendação válida é aquela que se justifica à base de um consenso razoável, no contexto de um discurso prático." (ROUANET, 2001, p. 290) Assim, é importante fazer uma distinção entre um consenso verdadeiro, fundado, e um consenso aparente. Um consenso fundado seria aquele que é:

[...] obtido num processo de argumentação que permite aos participantes levar às últimas consequências o princípio da dúvida radical, sem qualquer limitação. Isto significa que os

${ }^{4}$ Discurso teórico propõe a problematização de uma afirmação e discurso prático inicia a problematização de uma recomendação (ordem ou proibição) (ROUANET, 2001). 
participantes devem ter a liberdade não somente de criticar afirmações e recomendações, no marco dos sistemas conceituais e linguísticos existentes, mas de rever esses mesmos sistemas, num processo de radicalização progressiva que pode transcender o próprio marco teórico ou institucional em que os discursos foram instaurados (ROUANET, 2001, p. 292).

Para Habermas, as condições para um consenso fundado dependem de uma situação linguística ideal, que é aquela em que "[...] a comunicação não é perturbada nem por coações externas ao processo comunicativo, nem por distorções internas a esse processo, resultantes de uma deformação sistemática da comunicação." (ROUANET, 2001, p. 294). O consenso fundado também exige que os participantes sejam capazes de fazer uma tríplice distinção entre realidade e ilusão, entre essência e manifestação externa e entre fatos e valores. Para que todos os participantes tenham chances simétricas de praticar atos linguísticos (propor enunciados), eles devem ser capazes de praticar atos comunicativos (abrir e perpetuar discursos através de fala e contrafala, perguntas e respostas), atos constatativos (fazer e refutar afirmações, explicações, interpretações, de modo que nenhuma opinião fique imune à crítica), atos representativos (exprimir livremente atitudes, sentimentos e intenções, sem autoilusão e sem iludir a outrem) e atos regulativos (ordenar, proibir, prometer e receber promessas, dar contas de seu comportamento ou exigir que outros o façam).

O problema é que frequentemente os indivíduos agem de forma inconsciente, pois sofrem obstruções de caráter psíquico ou ideológico, o que ameaça os atos representativos, ou seja, a expressão livre de atitudes, sentimentos e intenções isentas de ilusão, que estão sujeitos à falsa identificação e à falsa projeção. Por meio da falsa identificação, integram-se todos os indivíduos no sistema. Nisso também reside o fenômeno da imitação, a mímesis, por meio da qual o indivíduo assimila-se à realidade que percebe, ainda que não se identifique totalmente com ela. Através da falsa projeção, o indivíduo expulsa de si sentimentos e desejos que não admite em si mesmo, localizando-os no exterior. O indivíduo então constrói uma realidade delirante, mostrando-se incapaz de uma reflexão subjetiva que o faria colaborar com a construção do real. Teríamos assim o indivíduo que se deixa integrar à cultura dominante (falsa identificação) e que abre mão da sua própria capacidade de criação (falsa projeção). A falsa identificação e a falsa projeção impedem a autonomia do sujeito e obliteram sua percepção do real. Dessa forma, a situação linguística ideal é improvável, mas fornece o único critério possível para avaliar se há ou não um consenso fundado. A situação linguística ideal não é um objetivo, pois dificilmente será alcançada, mas é um modelo de referência que permite criticar as condições discursivas existentes tendo como parâmetro condições idealizadas. Assim, para Rouanet (2001, p. 299), Habermas dessa forma propõe um novo quadro de referência que possibilita repensar a crítica do conhecimento e da cultura:

É possível, por um lado, reexaminar a questão dos interesses cognitivos, integrando-os numa moldura que nos leve a distinguir questões relacionadas com a constituição transcendental dos objetos e questões relacionadas com a validade do saber, e refletir sobre o próprio estatuto epistemológico de uma teoria crítica, que se proponha a denunciar a comunicação sistematicamente deformada e propor projetos alternativos de organização social; e é possível, por outro lado, aprofundar a crítica da ideologia e da cultura.

No contexto da teoria do conhecimento, as explicações causais, baseadas em um saber empírico-analítico, podem ser convertidas em um saber tecnicamente utilizável, e as explicações narrativas, que se apoiam em um saber hermenêutico, podem ser transformadas em um saber prático. O estatuto de uma teoria social crítica está sujeito a um duplo a priori: "A objetividade de seus enunciados é condicionada pelo interesse emancipatório, e sua aspiração de validade, como a de toda ciência, só pode concretizar-se em contextos discursivos." (ROUANET, 2001, p. 302-303) E o que significa formular enunciados objetivos à luz do interesse emancipatório? "Significa assumir, metodologicamente, o ponto de vista (hipotético) da situação linguística ideal, a única susceptível de gerar um consenso fundado, isto é, uma situação em que os interessados sejam protagonistas, em que todos protagonistas sejam livres e iguais." (ROUANET, 2001, p. 303) O papel do cientista crítico é denunciar a situação existente (que suprime os interesses gerais) comparando-a com uma situação na qual todos os interessados pudessem participar de um processo de 
formação discursiva da vontade. O problema enfrentado pela teoria crítica é que ela é forçada a pensar discursivamente

[...] situações em que a ação discursiva já foi ultrapassada ou ainda não foi percebida como essencial. Ela realiza, no plano do pensamento, o discurso que não pode se instaurar no plano da realidade social. Ela pensa o que os homens pensariam se pudessem pensar. (...) $\mathrm{O}$ cientista antecipa (provisoriamente) proposições cuja confirmação só pode ocorrer no futuro, em contextos discursivos adequados. Mas essas hipóteses não são fantasistas, e sim fundadas na realidade de um processo comunicativo que exige a justificação discursiva de todo saber, inclusive o saber da teoria crítica. (ROUANET, 2001, p. 304)

Em outras palavras, a teoria crítica ao "pensar o que os homens pensariam se pudessem pensar" também está agindo cientificamente, pois antecipa proposições que são possíveis de ocorrer no futuro e essas proposições não são fantasias, pois estão fundadas na realidade. A questão da ideologia é tratada por Habermas como uma deformação sistemática do processo comunicativo, que procura camuflar relações de violência. No contexto da legitimação tecnocrática, as normas são substituídas por regras, que representam a encarnação da racionalidade instrumental, de modo que não estão abertas à revisão por intermédio de discursos práticos. Habermas, no entanto, considera que a longo prazo a política tecnocrática não conseguirá subsistir, pois a exigência de justificabilidade das normas, que é inerente à ação comunicativa, está arraigada na própria autoformação da espécie humana. O que Habermas quer dizer é que as contradições do capitalismo tardio em contraste com a evolução da racionalidade humana colocarão todo o sistema em xeque. O próprio Estado, ao tentar bloquear o processo comunicativo, impedindo a abertura de discursos práticos, vem criando áreas de conflito na sociedade civil que fazem essa racionalidade evoluir. Do mesmo modo, acrescentamos que as novas tecnologias de informação e a própria internet, estão abrindo espaço para esse processo comunicativo acontecer. Se em um primeiro momento esse processo comunicativo pode parecer deficiente, ao longo do tempo e do aprendizado democrático, ele tende a se aprimorar.

Para Habermas, há um paralelo entre a evolução ontogenética do ser humano, que alcança novos níveis de maturidade em relação às operações formais inerentes ao seu desenvolvimento cognitivo, que o leva a alcançar o julgamento hipotético-dedutivo, e a evolução filogenética da humanidade, que também tende a alcançar novos patamares em relação às exigências éticas. Assim, paradoxalmente, vivemos na era da ideologização total identificada por Adorno e Horkheimer, mas também a época em que pela primeira vez se coloca a possibilidade de se superar as formas atuais e futuras de falsa identificação e falsa projeção, como percebem Marcuse (1964; 1973) e Habermas (1981; 2010). O antídoto para falsa projeção e a falsa identificação é a crítica, pois, assim como a psicanálise, a teoria crítica faz uma rememoração, não só dos vínculos esquecidos, mas principalmente dos conteúdos, tentando recuperar o passado. Além disso, enquanto a interpretação psicanalítica se preocupa com o recalque, a crítica da cultura se volta para a repressão, pois o recalque é um fenômeno do inconsciente e a repressão um fenômeno da sociedade. A crítica da cultura e a interpretação analítica têm em comum lembrar o esquecido e conscientizar o inconsciente.

Na nossa visão, Habermas, apesar de partilhar com os demais frankfurtianos a crítica da ideologia tecnocrática e da ciência e da técnica, prefere correr este risco de fazer um apelo aos procedimentos e às metodologias, pois não acredita que as consciências estejam pervertidas de forma tão irreversível que não seja possível repensar esses procedimentos e metodologias segundo parâmetros que estejam de acordo com o interesse prático e o interesse emancipatório. Daí ele se declarar um funcionalista historicamente orientado, pois não abandona o interesse técnico, mas considera que uma outra técnica é possível desde que a ação comunicativa seja buscada.

De acordo com Rouanet (2001, p. 318), Habermas admite, no entanto, que a teoria da ação comunicativa tem lacunas, uma vez que:

[...] a teoria da comunicação supõe a problematização discursiva de expectativas de validade, mas não reflete expressamente sobre as constelações objetivas e subjetivas em que acesso ao discurso seja estruturalmente vedado aos participantes de uma interação. 
Em outras palavras essa teoria não aponta uma saída para a superação da falsa identificação e da falsa projeção do ponto de vista psíquico. Para preencher essas lacunas, Habermas recorre ao modelo freudiano. Habermas argumenta que Freud prossegue com a reflexão hermenêutica de Dilthey e vai além, pois, enquanto Dilthey procura interpretar expressões simbólicas intencionais distorcidas, Freud engloba também o que não é conscientemente intencionado. A hermenêutica tradicional remove os erros e distorções do texto; para Freud, essas deformações têm um sentido imanente, pois não se trata de entender um texto corrupto, mas a própria estrutura da corrupção. O sujeito freudiano possui um "território estrangeiro interno", uma parte dele que se tornou inacessível para ele mesmo e da qual somente ele pode se reapropriar, motivo pelo qual a categoria essencial da psicanálise é a autorreflexão. O estatuto da psicanálise, enquanto ciência crítica, emana da intersubjetividade da relação terapêutica, que começa assimétrica, mas evolui para uma condição de igualdade.

A psicanálise é uma sistematização da intersubjetividade sui generis que se produz entre analista e analisando - um diálogo no início assimétrico, entre duas partes objetivamente desiguais, mas visando induzir no paciente um trabalho de autorreflexão que o leve a emancipar-se de causalidades incompreensíveis, e o torne apto a participar, em condições de igualdade, dos processos discursivos. (ROUANET, 2001, p. 320-321)

A autorreflexão ajuda o sujeito a dissolver as estruturas reificadas e para isso a psicanálise se manifesta como interpretação geral. A narrativa generalizada é o conflito edipiano ${ }^{5}$ e o trabalho do analista é ajudar o analisando a preencher os nomes e papéis típicos dessa narrativa, justapondo o genérico ao individual, de forma que o individual conte sua própria história tendo como pano de fundo uma história universal. Assim, a psicanálise se encontra a meio caminho da ciência empírico-analítica e da ciência hermenêutica, pois distingue-se da ciência empírico-analítica, porque a proposição científica é externa ao objeto e a proposição psicanalítica, que no caso é a interpretação, só é válida se aceita pelo objeto - o sujeito que está sendo analisado. Além disso, a não aceitação dessa proposição, fruto de uma interpretação, pelo analisando, não significa que ela seja inexata, pois pode evidenciar a resistência ao desvendamento de determinado material psíquico, de modo que ela fica em suspenso, a ser confirmada no curso do próprio processo de análise.

Em outras palavras, as proposições são possíveis de serem confirmadas, mas essa confirmação é distinta da verificabilidade que ocorre na ciência tradicional. Além disso, a psicanálise visa à compreensão hermenêutica da intencionalidade inacessível ao próprio sujeito, de modo que as explicações causais são dissolvidas, pois as causas são reconvertidas em motivos. Desse modo, podemos afirmar que a psicanálise está enraizada em um interesse emancipatório, que é a dissolução dos bloqueios à comunicação do sujeito consigo mesmo. A psicanálise é assim, indubitavelmente, uma ciência crítica, e o processo de investigação que lhe subjaz está diretamente ligado às condições transcendentais ${ }^{6}$ para a obtenção do conhecimento:

No movimento da autorreflexão, conhecimento e interesse constituem uma unidade. É somente quando essa unidade se torna transparente numa ciência crítica como a psicanálise, que se torna possível compreender com clareza a estrutura transcendental de interesses que

5 Segundo Freud $(1924 ; 1996)$, a inserção do pai, um terceiro que se impõe na relação mãe e filho, coloca limites ao desejo do menino pela mãe, instaurando-se o complexo de Édipo. A hostilidade do menino é dirigida para o pai, considerado o rival, que o ameaça de castração (ameaça simbólica que significa a interdição do desejo pela mãe). No caso da menina, é preciso abandonar o primeiro objeto de amor, que é mãe, e dirigir sua afetividade para o pai, de modo que o seu complexo de Édipo se instaura no momento que se descobre castrada, o que resulta em uma hostilidade dirigida à mãe, por não ter lhe dado um pênis e uma identificação com o pai, que tem um e pode the dar um falo representado por um bebê. A mãe então passa a ser considerada a rival. Nos dois casos, ao mesmo tempo, se estabelece uma culpa pelo desejo do incesto. Freud $(1924 ; 1996)$ afirma que isto faz parte do desenvolvimento da sexualidade de todos os seres humanos, sendo que uma travessia saudável do Édipo significa a superação deste desejo pelos pais e a capacidade de dirigir o amor sexual para um parceiro adulto, o que aponta para o alcance da genitalidade e o abandono de outras fases do desenvolvimento da sexualidade, como a fase oral e a fase anal. Perturbações nesse processo estabelecem neuroses (fobia, obsessão e histeria) em diferentes graus.

${ }^{6}$ Transcendental no sentido em que se opõe a empírico, ultrapassando a lógica e o formalismo da ciência. 
condicionam e possibilitam as ciências naturais e culturais. A partir da percepção do saber crítico como saber imediatamente interessado, é possível perceber a ciência empírica e a hermenêutico-cultural como igualmente interessadas, embora de forma menos imediata. (ROUANET, 2001, p. 324-325)

Em síntese, o saber psicanalítico é um saber crítico e um saber interessado, do mesmo modo que a epistemologia crítica frankfurtiana envolve um saber engajado. Como afirmamos anteriormente, o percurso feito pretendia evidenciar que no âmago da epistemologia crítica frankfurtiana está a epistemologia freudiana, de modo que tentar compreender a teoria crítica sem o auxílio do freudismo enfraquece o poder crítico da mesma. O mérito da psicanálise é fornecer para a teoria crítica um modelo de ciência que assume a forma de uma crítica na qual o interesse emancipatório é visível: estabelece-se assim uma mediação entre uma teoria que visa à transformação (a teoria crítica) e uma prática terapêutica (a psicanálise) que coloca esse interesse emancipatório em prática. Assim, uma vez depurada de sua autocompreensão naturalista, a psicanálise oferece um modelo para a ciência crítica, pois fornece

...uma teoria, derivada da reflexão metódica da experiência da comunicação sistematicamente deformada, e que visa dissolver as falsas objetivações através de propostas de interpretação em que os interessados possam, finalmente, reconhecer-se, reapropriando, assim, uma parte perdida de sua própria subjetividade. (ROUANET, 2001, p. 326)

Um dos desafios do percurso que ora realizamos é partir dessa teoria e modelo de ciência para chegar a uma indicação de como o interesse emancipatório pode ser reapropriado na prática pelos grupos e organizações. Logo, o que buscamos é lançar mão do modelo de ciência colocado pelo freudismo e da epistemologia crítica frankfurtiana para evidenciar as possibilidades emancipatórias práticas de uma coletividade, um grupo ou uma organização. No entanto, para cumprir esse objetivo, ainda será necessário compreender como ocorrem as mediações entre o indivíduo e a sociedade e como a psicanálise pode nos ajudar nesta tarefa, bem como apontar caminhos para a desalienação do sujeito e dos grupos aos quais ele pertence.

A dinâmica do recalque é uma das chaves para compreender como de uma comunicação deformada consigo mesmo, o indivíduo passa para uma comunicação deformada com os outros (ROUANET, 2001). Uma vez que o recalque é o processo pelo qual a sociedade inibe a transformação em ação de motivações indesejáveis, ele remove de circulação as interpretações simbólicas correspondentes a essas motivações, que se convertem em motivos inconscientes. O que foi removido da comunicação pública fica sujeito a outra gramática, a gramática do inconsciente, que tem como características a deformação, a condensação e a transformação no seu contrário. O símbolo linguístico removido da linguagem pública não pode mais ser comunicado, transforma-se em símbolo pré-linguístico (emocionalmente carregado e aderente a imagens e, assim, a comunicação real é substituída pela pseudocomunicação entre os sujeitos, que são incapazes de articular desejos incompatíveis com as normas sociais. Estes símbolos pré-linguísticos se infiltram na linguagem produzindo distorções. O material recalcado tenta aceder novamente à esfera pública, manifestando-se nos sonhos, nos atos falhos, nos chistes e nos sintomas neuróticos, que são formações do inconsciente. Pesquisando estas formações do inconsciente, a psicanálise se interessa pelo "refugo", por aquilo que não se encaixa no padrão de discurso do analisando, aquilo que "escapa" do inconsciente, que consegue driblar a vigilância do recalque. Além do recalque, a identificação, a projeção e a negação, que representam mecanismos de defesa psíquicos voltados para o exterior, também obstruem a comunicação. A tarefa da psicanálise consiste em inverter esse processo: o analista procura, por meio do processo de autorreflexão, fazer com que o material banido pelo inconsciente seja reintegrado na linguagem pública e também busca expulsar os símbolos pré-linguísticos infiltrados na linguagem. No entanto, a psicanálise não se atém apenas a decifrar lapsos de texto e corrigir deformações, pois também retifica a linguagem ao restabelecer a relação dialógica entre analista e o analisando. 
Rouanet (2001, p. 332) então argumenta que "[...] não é preciso construir uma ponte, sempre mais ou menos arbitrária, entre a falsa consciência individual e as legitimações ideológicas, porque ambas são radicadas numa mesma estrutura, que é a comunicação sistematicamente deformada." A falsa consciência individual e societária, fundamentadas na falsa identificação e na falsa projeção, estão mutuamente relacionadas e convergem para um mesmo ponto que é a não tematização das relações de poder. Esta repressão não é, como querem os marxistas mais ortodoxos, um simples efeito da forma de organização do trabalho e nem mesmo uma condição acidental e historicamente superável, pois trata-se de uma condição estrutural do próprio processo de humanização. Nas palavras de Rouanet (2001, p. 335-336, grifos nossos):

O progresso social da humanidade, se é delimitado pelas possibilidades técnicas em cada momento histórico, é alcançado, principalmente, não por qualquer automatismo da base, mas por uma atividade crítico-prática, na esfera da ação comunicativa, que contesta o poder e dissipa as ideologias legitimadoras que se tornam obsoletas. O processo pelo qual as ideologias são desmistificadas é análogo ao que leva à conscientização na relação clínica a autorreflexão. Os processos coletivos de autorreflexão, conduzidos por quadros e organizações que representam os grupos oprimidos, traduzem-se, como no caso do seu equivalente terapêutico, na dissolução das estruturas reificadas, e numa reapropriação de capítulos esquecidos da autobiografia desses grupos.

Dessa forma, Rouanet argumenta que a autorreflexão individual feita na terapêutica psicanalítica pode ser reproduzida pelos grupos, que por meio da dialogicidade dissolvem estruturas reificadas e se reapropriam do saber esquecido e oculto: neste ponto a epistemologia freudiana e a epistemologia habermasiana se entrelaçam. Rouanet (2001) ainda afirma que, na autorreflexão coletiva, a conscientização se realizaria sob as condições de um discurso terapêutico, e as estratégias formuladas têm que ser objeto de um discurso prático: todos os integrantes teriam que participar de ambos os discursos e precisariam estar focados no desenvolvimento de uma competência interativa. Concluindo, a epistemologia habermasiana, inspirada no freudismo, não só permite criticar o positivismo, como também oferece elementos para se pensar uma ciência social crítica, fundamentada no interesse emancipatório, visando explicitamente à intervenção na realidade.

Uma Alternativa para os Estudos Organizacionais: Suporte Teórico-Analítico e Estratégia de Investigação

Apresentaremos a seguir: (1) o suporte teórico-analítico, que é uma síntese do que foi discutido até agora para essa abordagem; e (2) uma estratégia de investigação - a pesquisa-ação articulada à socioanálise.

\section{Suporte Teórico-Analítico}

$\mathrm{Na}$ reconstrução epistemológica que realizamos entrelaçamos à articulação entre a epistemologia frankfurtiana e a epistemologia freudiana, a epistemologia habermasiana, concluindo a composição teórica da abordagem freudo-frankfurtiana. Com a intenção de guiar os leitores, sintetizamos, a seguir, as características do suporte teórico-analítico oferecido pela abordagem freudo-frankfurtiana, mas fazemos a ressalva de que esse guia não deve ser utilizado como via de simplificação, pois é preciso entender a essência dos conceitos, o que só é possível de ser realizado seguindo todo o percurso teórico e analítico anteriormente apresentado. A ideia da síntese aqui apresentada é fazer o leitor ou leitora rememorar o que foi discutido antes de passar para a discussão dos caminhos metodológicos e da estratégia de investigação.

(1) Forma de Pensar a Ciência: A ciência social se orienta para a emancipação e sua meta é a transformação do todo, de modo que ela é guiada pelo interesse emancipatório, que articula os interesses técnicos e práticos. 
(2) Forma de Explicar o Mundo: Os fatos sociais só podem ser compreendidos em conexão com processos sociais reais, que não se fundamentam exclusivamente por ponderações lógicas, mas precisamente nas contradições. A lógica de pensamento que permite isso é a dialética.

\section{(3) Premissas Epistemológicas e Filosóficas:}

- A busca do conhecimento se baseia na autorreflexão individual e coletiva para que o interesse emancipatório seja reapropriado pelos indivíduos e grupos;

- O conhecimento a priori e as proposições especulativas são válidos, pois desinibem o pensamento e favorecem a criação de conhecimento;

- O princípio da não identidade é utilizado, ou seja, admite-se que não é possível a total reconciliação entre os interesses dos indivíduos e os interesses da sociedade, mas sem perder de vista que mudar a realidade em que se vive é um projeto viável.

\section{(4) Premissas Metodológicas e Analíticas:}

- O método é o meio para se realizar a ciência social e não o seu objetivo, pois a ciência social deve refletir sobre sua essência e finalidade;

- O método a ser seguido é a crítica imanente, ou seja, o mergulho no conteúdo do objeto até que ele se revele, complementada pela dialética, que possibilita ver as contradições e relativizar as conclusões;

- O método envolve a busca de uma situação linguística ideal com os pesquisados e a possibilidade, por meio da autorreflexão, de superar a falsa identificação e a falsa projeção: a via para isso é o próprio método psicanalítico;

- A experiência espontânea tem mais importância enquanto fenômeno a ser estudado do que a experiência regulamentada: a observação é preferível à experimentação;

- O fenômeno singular encerra em si toda a sociedade, de modo que o foco do cientista social e do estudioso de organizações é a relação entre o particular e o universal. O vestígio, o fato isolado, os pequenos indícios são elementos que podem levar a algo maior;

- Não faz sentido utilizar conceitos como hipótese e testabilidade: a verificação é substituída pela possibilidade de confirmação;

- Não existe a "verdade", mas verdades provisórias, e a incerteza é intrínseca às realidades estudadas. Além disso, o erro faz parte do processo de conhecimento;

- A partir de uma contradição, ou de um erro, é possível percorrer toda uma cadeia associativa que leve ao esclarecimento dos fenômenos, ou seja, novas interpretações e explicações;

- Uma interpretação que não faz sentido em um contexto não está necessariamente errada, pois pode fazer sentido em outro contexto, com adaptações;

- Não basta explicar, interpretar e compreender, pois é fundamental sustentar a posição dialética de que os fenômenos podem ser isto e aquilo ao mesmo tempo.

\section{Pesquisa-Ação e Socioanálise}

A estratégia de pesquisa-ação se encontra bastante alinhada como a abordagem freudo-frankfrutiana anteriormente discutida, respondendo aos requisitos do suporte teórico-analítico apresentado, especialmente às premissas metodológicas e analíticas. A própria definição de pesquisa-ação já aponta para isso: 
[...] a pesquisa-ação é um tipo de pesquisa social com base empírica que é concebida e realizada em estreita associação com uma ação ou com a resolução de um problema coletivo e no qual os pesquisadores e os participantes representativos da situação ou do problema estão envolvidos de modo cooperativo ou participativo.” (THIOLLENT, 1985; 2011, p. 20)

A pesquisa-ação torna-se a ciência da práxis exercida pelos técnicos no âmago de seu local de desenvolvimento. O objeto da pesquisa é a elaboração dialética da ação num processo pessoal e único de reconstrução racional pelo ator social. Esse processo é relativamente libertador quanto às imposições dos hábitos, dos costumes e da sistematização burocrática. A pesquisa-ação é libertadora, já que o grupo de técnicos se responsabiliza pela sua própria emancipação, auto-organizando-se contra hábitos irracionais e burocráticos de coerção. (BARBIER, 1996; 2007, p. 59)

Em outras palavras, a pesquisa-ação é uma construção coletiva na qual os pesquisadores atuam como facilitadores da resolução de problemas que afetam o grupo, que procura se organizar de acordo com a lógica da ação comunicativa habermasiana. Segundo Thiollent $(1985 ; 2011)$, a pesquisa-ação é uma estratégia metodológica de pesquisa social que:

(1) Exige uma ampla e explícita interação entre pesquisadores e pessoas implicadas na situação investigada, sendo que essa interação resulta na ordem de prioridade dos problemas a serem pesquisados e nas soluções a serem encaminhadas sob forma de ação concreta;

(2) Tem como objeto de investigação não as pessoas, mas a situação social e os problemas de diferentes naturezas encontrados nessa situação;

(3) Tem como objetivo resolver ou, pelo menos, esclarecer os problemas da situação observada;

(4) Envolve um processo de acompanhamento das decisões, das ações e de toda atividade intencional dos atores da situação;

(5) Não se limita a uma forma de ação e ao ativismo, pois pretende aumentar o conhecimento dos pesquisadores e o conhecimento, ou nível de consciência, das pessoas e grupos considerados.

A pesquisa-ação tem assim dois objetivos: um objetivo prático e um objetivo de conhecimento. Por esse motivo, ela permite abrigar todos os interesses cognitivos abordados por Habermas, que discutimos na seção anterior: o técnico, o prático/comunicativo e o emancipatório. Segundo Thiollent (1985; 2011), esse tipo de pesquisa é composto das seguintes etapas:

(1) Diagnóstico ou Fase Exploratória: quando se avalia a disponibilidade dos pesquisadores e do grupo a realizar uma pesquisa com essas características a fim de obter o consentimento e comprometimento de todos;

(2) Seminário: é uma forma de organização do grupo utilizada para estabelecer as etapas, a divisão de tarefas e os parâmetros de monitoramento da pesquisa, sendo instaurado desde o início dos trabalhos e convocado em vários momentos da investigação;

(3) Definição do Tema da Pesquisa: o tema é definido em um processo de discussão com os participantes;

(4) Colocação dos Problemas: os problemas a serem solucionados também são definidos em um processo de discussão com os participantes; 
(5) Definição do Lugar da Teoria: a vocação da pesquisa-ação é prática, mas a preocupação com teoria está colocada principalmente quando os problemas a serem tratados não são tão evidentes no início e trazem diversas problemáticas sociológicas;

(6) Definição de Hipóteses: o uso de procedimento hipotético não está excluído, mas se recorre a ele de forma suavizada - em geral se encontram várias hipóteses ou há polarização de hipóteses excludentes;

(7) Definição de Campo de Observação e Amostragem: o ideal é fazer a pesquisa com o universo do grupo, excluindo a amostragem e recorrendo a ela só quando não for viável fazer de outra forma;

(8) Coleta de Dados: efetuadas pelos grupos de observação definidos, recorrendo a diversas técnicas entrevistas, histórias de vida, aplicação de questionários, intervenções, entre outras;

(9) Análise de Dados: considerada uma etapa de aprendizagem por parte do grupo e também o momento no qual se procura equilibrar o saber dos especialistas e o saber dos interessados;

(10) Plano de Ação: procura estabelecer alguma forma de ação planejada a partir das análises realizadas;

(11) Avaliação de Resultados: os resultados obtidos das ações são analisados e avaliados pelos pesquisadores e pelo grupo.

Trata-se de uma estratégia de investigação científica aberta, que recorre à forma de experimentação, mas que ocorre em situação real, sem possibilidade de se isolarem variáveis, opondo-se ao positivismo. É também uma estratégia de pesquisa dialógica, que faz referência à autorreflexão coletiva e à ação comunicativa de Habermas, na medida em que apresenta características que são próprias dos processos argumentativos e deliberativos. Como aponta Thiollent $(1985 ; 2011)$, os problemas a serem estudados e resolvidos são colocados diretamente pelos pesquisadores e participante; as soluções apresentadas pelos pesquisadores são discutidas e modificadas pelos participantes; os meios de ação a serem implementados são deliberados pelo grupo; e os resultados da pesquisa e das ações desencadeadas também são discutidos por todos.

Thiollent (1997; 2009) também discute a adequação da pesquisa-ação para as organizações, pois considera a estratégia apropriada na medida em que consiste na identificação e solução de problemas organizacionais por meio da implicação das pessoas que vivem e trabalham nelas. $\mathrm{O}$ autor cita que internacionalmente há uma longa tradição no uso de pesquisa-ação nas organizações, especialmente no mundo anglo-saxão, mas que essa havia perdido espaço com o avanço de modismos gerenciais imediatistas como a reengenharia e a imitação do modelo japonês. No entanto, vem sendo resgatada e ao nosso ver poderia ser mais explorada nos estudos organizacionais, pois traz perspectivas de mudança e práxis, principalmente se associada à abordagem freudo-frankfurtiana. .

A pesquisa-ação também remete à intervenção socioanalítica de René Lourau. A análise institucional deste autor, que se expressa na socioanálise, se distancia de abordagens behavioristas e psicossociais que geram novas formas de gestão da subjetividade, uma vez que buscam meramente a melhoria da qualidade de vida no trabalho, sem pretensões emancipatórias. O que está em questão é se valer do método psicanalítico como inspiração para realizar uma intervenção nas organizações, ou seja, uma socioanálise, que é uma perspectiva clínica utilizada para gerar "crises" que estimulam a prática da autogestão e de outras manifestações instituintes e contrainstitucionais, como veremos a seguir.

Lourau $(1970 ; 1975)$ busca na psicanálise freudiana materiais para sua versão da análise institucional, enfatizando principalmente as discussões de Freud sobre a psicologia social, evidenciando que há um paralelismo entre o vínculo libidinal e o vínculo social, pois o grau de coesão de um grupo depende da ilusão da presença de um chefe que ama todos ao mesmo tempo (referência ao pai/mãe), da constituição de uma organização coatora que controla a filiação e a expulsão dos membros e da presença de uma ideologia que 
contribui para a coesão do conjunto, sendo que os vínculos ideológicos são insuficientes se não forem suficientemente libidinizados. Por outro lado, em Psicologia de Grupo e Análise do Ego (FREUD, 1921; 1996), fica clara a falsa oposição entre a clínica individual e a clínica social, sendo que, para Lourau (1970; 1975), teríamos a psicanálise como estudo da estrutura inconsciente e a análise institucional como estudo da estrutura das relações sociais, mas não no sentido de isolar os dois tipos de estudo, pois eles são interdependentes.

Em seguida, Lourau $(1970 ; 1975)$ busca materiais da psicoterapia institucional para continuar a composição de sua análise institucional. A psicoterapia institucional nasce nos hospitais e instituições de saúde mental, organizando-se em três fases: (1) fase empírica: caracterizada pela modificação de atitude dos cuidadores em relação aos pacientes, que passam a ser reconhecidos como sujeitos; (2) fase ideológica: a psicoterapia de grupo emerge como uma forma terapêutica de abordar os pacientes, cujo efeito é provocar um exame das relações sociais no interior da instituição, que exige uma reestruturação delas, pois os pacientes são tomados como agentes da própria cura, devendo, portanto, ter cada vez mais controle das atividades da instituição, de modo que a autogestão aparece como um projeto-limite; (3) fase teórica: faz uma crítica das duas primeiras fases, pois verifica-se que, na autogestão da organização, os promotores dessa "pequena revolução", entregues à alegria de instituir, às vezes se esquecem de se perguntar o que estão fazendo ao instituírem. $\mathrm{O}$ passo seguinte é sair do plano consciente, no qual esta autogestão está ocorrendo, para alcançar o plano do inconsciente do grupo, questionando as novas posições de poder dos envolvidos, o que aponta para o fato de que a cura não se sustenta pelo médico e pelo próprio paciente, mas por uma rede intricada de pessoas e de relações que contribuíram para isso. Esse desenvolvimento em três fases é mais um elemento que passa a constituir a análise institucional de René Lourau.

Para Lourau (1970; 1975), em uma intervenção deve ficar clara a diferença entre a demanda técnica do mercado de trabalho e a demanda social, que se refere à educação para mudanças de atitudes que não se limitam ao aumento da produtividade, mas que tenham repercussões relevantes para a coletividade. Lourau $(1970 ; 1975)$ então vai buscar na intervenção pedagógica mais elementos para sua análise institucional. Seu primeiro passo é fazer uma distinção entre instituição e organização a partir do trabalho de Robert Pagès. O conceito de instituição teria três momentos: (1) momento de universalidade: nesse a instituição compensa sua fraca funcionalidade com uma positividade mais ideológica do que prática, ou seja, a instituição ainda não funciona a contento, mas se estabelece como ideia-força; (2) momento de particularidade: nesse a instituição se encontra em permanente evolução quanto as suas finalidades, sendo que a iniciativa, os talentos e o carisma individuais contribuem muito para isso; (3) momento de singularidade: nesse a instituição se estabelece enquanto organização com funcionalidade e finalidades muito claras. Em outras palavras, o conceito de instituição é polissêmico, constituindo-se de momentos instituintes, a partir dos quais as regras de funcionamento, as funções (serviços, postos, responsabilidades), os papéis (chefias, subordinados) e os ritos são elaborados. Assim, é possível existir instituições e não existir uma organização, mas não há organização sem instituições.

Em seguida, Lourau (1970; 1975) aborda a intervenção pedagógica propriamente dita, explorando em primeiro lugar os conceitos de não diretividade e educação negativa, afirmando que a ideia central é questionar o saber instituído, ou seja, a naturalização do que se consideram boas práticas, além de acentuar não o caráter universal do saber, mas o caráter eminentemente problemático de cada indivíduo. Depois Lourau (1970; 1975, p. 256) passa a discutir a pedagogia institucional de Georges Lapassade, que seria “[...] o método que consiste em ordenar, pela análise permanente das instituições externas ${ }^{7}$, a margem de liberdade na qual o grupo-classe poderá autogovernar seu funcionamento e seu trabalho, assegurar a própria regulação

7 Instituições externas, segundo Lourau (1975, p. 256) seriam: “[...] as regras exteriores ao estabelecimento (instituição escolar) e à classe (turma de alunos), os programas, instruções, circuitos de autoridade, pessoal distribuído de acordo com a hierarquia, 'burocracia pedagógica', etc." 
pela criação de instituições internas ${ }^{8}$." A função da pedagogia institucional seria "[...] favorecer a socialização, permitindo aos ensinandos instituir, na medida do possível, sua organização, fazendo-os adquirir consciência das coações institucionais, sociais de sua aprendizagem.” Lourau (1970; 1975, p. 262) então afirma que é no momento da singularidade, ou seja, no momento em que a organização se estabelece, como já vimos, que deve se situar a autogestão, pois é nele que ocorre "[...] o controle do processo de simbolização, no qual é tomada a base material da instituição-classe (turma de alunos) ou escola, a saber, os recursos tecnológicos, as ligações com a economia, etc."

Assim, trata-se de colocar em jogo uma tríplice descoberta sobre o professor, ou do mediador do grupo, quando se consideram outros tipos de organização:

a) Seu saber é problemático, é um não saber, porque sabe que se coloca em uma relação negativa com os outros saberes. Daí resulta a. não diretividade.

b) Seu papel na estrutura libidinal do grupo é equívoco, porque o sistema de parentesco simbólico que sua intrusão perturba e arruma ao mesmo tempo, não o autoriza, senão imaginariamente, a tomar emprestado tal papel em vez de outro, pai autoritário, mãe protetora, companheiro ou irmão "semelhante". Daí a autogestão.

c) Sua posição no sistema institucional é ambígua, sendo ao mesmo tempo servidor do instituído e encarregado da função instituinte. Estando mal integrado no "sistema", acha-se obrigado a fazer os outros participarem de instituições, práticas e valores que lhe escapam. [...] O desconhecimento, a ingenuidade política, eis o seu destino. Daí a análise institucional. (LOURAU, 1970; 1975, p. 264)

As elaborações de Lourau são colocadas para instituições escolares, mas o método também se aplica para outras formas de organização. Lourau $(1970 ; 1975$, p. 266) passa a descrever, então, a intervenção socioanalítica, que seria a aplicação da sua análise institucional na prática dos grupos, coletividades e organizações. Esse tipo de análise institucional se inspira nos elementos que foram discutidos e engloba:

[...] de um lado um método de conhecimento indutivo, situado junto da análise funcional, estrutural, estruturo-funcional, e também junto de diversos modos de análise econômica, política, etc,, de outro, mais especificamente, um modo de análise em situação que se aproxima mais da clínica psicanalítica.

Dessa forma, a intervenção socioanalítica agrega os três interesses cognitivos de Habermas (interesse técnico, interesse prático/comunicativo e interesse emancipatório) na medida em que considera a análise funcional em conjunto com a análise psicanalítica. O que permite construir essa situação analítica é a hipótese de que é possível uma análise que transcenda os "jogos da verdade", próprios da psicossociologia e a "higiene social", típica das consultorias organizacionais. Assim, na socioanálise, as seguintes operações precisam estar presentes (LAPASSADE e LOURAU, 1971; 1972):

- desvendar o que está oculto na solicitação de intervenção;

- analisar os limites colocados pelo coletivo analisado à autogestão das sessões;

- buscar o "não dito institucional", ou seja, os rumores, os segredos e as filiações sociais do grupo;

- averiguar se há filiação dos membros a outras perspectivas que não sejam a da organização;

\footnotetext{
${ }^{8}$ Instituições internas, segundo Lourau (1975, p. 256) seriam: "[...] de um lado as regras interiores do estabelecimento (instituição escolar), de outro lado 'o conjunto das técnicas institucionais', como o conselho (escolar) [...]"
} 
- elaborar ou elucidar o que aqueles que se desviam da lógica dominante no coletivo provocam nos outros membros do mesmo.

Em linhas gerais, quando se realiza a socioanálise, procura-se mobilizar as forças instituintes e considera-se que, a partir da autogestão, as pessoas podem oferecer os elementos para a análise e a elucidação de estruturas de funcionamento da organização, bem como buscar soluções para o impasse que representam (ALTOÉ, 2004). Nesse contexto, o analista institucional é um terceiro, que procura favorecer o debate, revelar o "não dito institucional" e estimular a busca de uma nova institucionalização. Assim, o seu objetivo não é uma terapia social, uma psicoterapia institucional, mas a subversão do instituído, de modo que seu projeto está mais do lado da verdade do que da eficiência.

As técnicas de intervenção pedagógica são úteis no processo de socioanálise e elas envolvem as seguintes práticas (LAPASSADE, 1974; 1977):

- o pedido de intervenção e de propostas precisa ser do grupo;

- o grupo que sofrerá a intervenção deve ser informado da natureza do método que se quer empregar e os motivos pelos quais se está empregando o mesmo, de modo que o analista encarregado precisa definir suas atitudes e os limites de sua intervenção;

- a solução dos problemas deve ser uma tomada coletiva de decisões da qual o analista é apenas um facilitador;

- as propostas do analista não podem ser apoiadas emocionalmente por ele, de modo a parecerem ordens ou ameaças;

- a intervenção do analista no conteúdo, ou seja no próprio trabalho, deve ser discreta, de modo que o grupo precisa ser estimulado com materiais a serem analisados e não com discursos orais.

Lapassade $(1974 ; 1977)$ reconhece que, na primeira etapa, os envolvidos podem ficar surpreendidos com a novidade da experiência, permanecendo inertes, à espera da intervenção do analista (vírgula) sendo essa etapa a mais penosa, de modo que se deve esperar pacientemente que os envolvidos cheguem a formas válidas de organização. Na segunda etapa, emergem discussões sobre uma organização possível que possa contentar os desejos de todos, de modo que a intervenção do analista começa a ser solicitada nesse sentido, ao que ele deve responder de maneira curta e discreta. Na terceira etapa, o grupo se engaja no trabalho propriamente dito e aqui o analista pode começar a comunicar seu saber e experiência, pois os envolvidos não vão mais registrar mecanicamente "tomando notas": vão interagir criticamente com os conteúdos.

Segundo Lourau (1970; 1975), estariam disponíveis os seguintes instrumentos de análise para averiguar o nível de distanciamento e aproximação do grupo em relação à autogestão, que servem de guia para o analista:

(1) Segmentaridade: pressuposto de que há um consenso ou regra exterior ao grupo, funcionando como a ideologia dessa comunidade de interesses convergentes que o transforma em um "grupo-objeto";

(2) Transversalidade: condição necessária para que um "grupo-objeto" se transforme em "gruposujeito", ou seja, consciência do grupo de sua polissegmentariedade e de sua capacidade de ação instituinte;

(3) Distância Institucional: componente objetivo e subjetivo da consciência que os sujeitos têm de sua não integração ao grupo, da insuficiência em seus modos de pertencer ao grupo e da falta de transversalidade na ação do grupo ao qual pertencem;

(4) Distância Prática: grau de afastamento dos sujeitos em relação à base racional das normas institucionais e das bases racionais das técnicas do grupo; 
(5) Implicação Institucional: o conjunto de relações que existem, conscientemente ou não, entre os sujeitos e o sistema institucional;

(6) Implicação Prática: o conjunto de relações reais que os sujeitos mantêm com a base material das instituições;

(7) Implicação Sintagmática: conjunto de relações interpessoais nos sintagmas sociais, que são os grupos efêmeros ou permanentes, grandes ou pequenos;

(8) Implicação Paradigmática: consciência dos sujeitos sobre o que é possível ou não é possível saber, fazer ou pensar no grupo;

(9) Implicação Simbólica: grau de sociabilidade (vínculo social) entre os sujeitos do grupo;

(10) Transferência Institucional: refere-se aos fenômenos de transferência entre o analista e o grupo.

Esses parâmetros de análise possibilitam avaliar o nível de autogestão do grupo, na medida em que traduzem a capacidade de ação instituinte do mesmo, ou seja, permitem definir se tratamos de um "grupo-sujeito" ou de um "grupo-objeto" por meio da análise de sua segmentariedade e transversalidade. Já a distância prática e a distância institucional apontam se há possibilidade de um "grupo-objeto" se tornar um "grupo-sujeito" e romper com o instituído. Essas análises permitem estabelecer as bases da intervenção, ou seja, da socioanálise, o que implica, por meio da própria análise, a instituição de uma "crise", se assim for a vontade do grupo, bem como de uma cuidadosa elucidação das relações transferenciais e contratransferenciais. Neste ponto é que o paralelismo com o método psicanalítico fica mais evidente. Mas como se caracteriza o método psicanalítico afinal? Freud discute o método psicanalítico e suas implicações em diversos textos, mas há uma boa síntese em Esboço de Psicanálise (1938/1996), um de seus últimos escritos. Sem deixar de recorrer a esse material, utilizamos também as quatro fases do tratamento psicanalítico didaticamente identificadas por Nasio (1999):

- Primeira Fase - Retificação Subjetiva: Ocorre nas primeiras entrevistas com o paciente, quando o psicanalista intervém, produz e introduz uma retificação subjetiva no primeiro gesto deste paciente, que foi a decisão de recorrer à ajuda de um analista. É a fase de tentar identificar a demanda implícita da análise, uma vez que em geral a demanda de fato nunca é explicitada, de modo que a retificação subjetiva procura levar o paciente a colocar em questão qual é a sua verdadeira demanda.

- Segunda Fase - Sugestão: É a fase inicial da análise na qual o analista realiza dois atos psicanalíticos: (1) aceitar analisar o paciente, reafirmando seu interesse nele; e (2) enunciar a regra fundamental da análise, que consiste em deitar no divã e falar, sem restrições, que lhe vier à cabeça. Essa regra é chamada de associação livre e leva à rememoração de acontecimentos esquecidos, traumáticos ou não, retidos no inconsciente, sendo gerenciada pelo analista que pode pedir elucidação de determinados pontos levantados pelo paciente. Esses dois atos ajudam na instalação de um "quadro transferencial" ou de "sugestão", também conhecida como "demanda de amor" do paciente em relação ao analista.

- Terceira Fase - Transferência: É a fase mais fecunda do tratamento, que consiste na transferência propriamente dita, quando a demanda de amor do paciente em relação ao analista sofre uma decepção, o que torna mais clara para o analista a verdadeira demanda do paciente. Chama-se transferência justamente porque consiste na transferência dos afetos dirigidos às figuras parentais à figura do analista. É nessa fase que o paciente é confrontado com a falta e é também nela que se instala a resistência do analista, também conhecida como contratransferência em relação ao paciente, pois ele precisa lidar com os próprios sentimentos de maneira a não impedir a evolução do paciente, o que envolve preservar a independência do mesmo; 
- Quarta Fase - Interpretação: É a fase na qual o analista gerencia a transferência e a contratransferência, pois o objetivo é que se faça silêncio para que o paciente lide sozinho com a falta, de modo que possa interpretá-la. É nessa fase que surge a resistência do paciente às interpretações que lhe ocorrem, que são facilitadas pelo analista, instaurando-se a "crise".

Vale notar que no curso da associação livre a tarefa do analista é fazer com que o material banido pelo inconsciente seja reintegrado na linguagem pública, daí seu foco se voltar para o que não se encaixa no discurso do paciente, ou seja, o refugo, sendo de seu vívido interesse os sonhos, os chistes e os atos falhos. Mas o que podemos dizer a respeito da crise instalada? Em Análise Terminável e Interminável, Freud (1937; 1996, p. 248) elucida um pouco mais a questão, ao discutir a técnica psicanalítica:

[...] essa é a técnica que utilizamos ao tratar um conflito que já é presentemente ativo. Procurarmos levar esse conflito a um ponto culminante, desenvolvê-lo até seu tom mais alto, a fim de aumentar a força instintual disponível para a solução. A experiência analítica ensinou-nos que o melhor é sempre inimigo do bom e que em todas as fases de restabelecimento do paciente, temos que lutar contra sua inércia, que está pronta a se contentar com uma solução incompleta.

Ainda falta responder uma questão: qual é o propósito da análise e como ela chega ao fim? O propósito da análise é a resolução dessa e de outras crises, de modo que o paciente possa superar os sintomas e que um dia seja capaz de analisar a si mesmo, ou seja, que ele tome para si este processo de conhecer o seu inconsciente e se liberte do analista. Freud (1937/1996) admite que esse é um processo penoso e que é polêmico dizer que algum dia ele terá fim, pois novas questões sempre surgem, e pontos que não foram abordados por um analista podem ser despertados por outros. As fases listadas, bem como o propósito da técnica analítica, podem ser analogamente identificadas no processo de análise de um grupo e remetem à autorreflexão coletiva, defendida por Habermas como a base da ação comunicativa.

\section{Considerações Finais}

Este artigo se propôs a apresentar a abordagem freudo-frankfurtiana, sua estratégia de pesquisa para os estudos organizacionais, que é orientada pelo interesse emancipatório, tecnicamente aplicável e voltada para a atividade prática/comunicativa. Ao longo do texto evidenciamos como esta abordagem e metodologia conjugam teoria e práxis, apontando novos procedimentos para pesquisas empíricas e intervenções de caráter crítico. A proposta alternativa apresentada coloca a emancipação e a autonomia não só como um tema, mas também como um valor a ser buscado pela própria prática da pesquisa. Para isto, buscamos nas epistemologias frankfurtiana, freudiana e habermasiana e na estratégia de pesquisa-ação associada à socioanálise aportes que possibilitassem este tipo de prática.

A reconstrução epistemológica elaborada para constituir a abordagem freudo-frankfurtiana apresenta uma alternativa para as ciências sociais e os estudos organizacionais, porque se fundamenta em uma base teóricaanalítica sólida, constituída pela lógica dialética e por uma orientação para emancipação que se expressa pela articulação dos interesses técnicos e práticos. Além disso, não nos limitamos a oferecer um suporte para análises teóricas, pois procuramos indicar saídas para a pesquisa organizacional que privilegiam a prática, uma vez que afirmamos que as investigações necessitam ter um objetivo de conhecimento, mas também um objetivo prático, de modo que o analista organizacional precisa pactuar com o grupo ou organização abordados quais são as metas coletivas da investigação, qual é o plano de ação a ser implementado e ainda realizar uma avaliação coletiva dos resultados.

A abordagem freudo-frankfurtiana parametriza e norteia a estratégia de pesquisa, realizando uma articulação entre epistemologia e metodologia que pode trazer grandes sinergias e resultados práticos para as investigações realizadas. A pesquisa-ação articulada à socioanálise tem o mérito de tornar a investigação um processo formativo que possibilita a transformação do grupo envolvido, pois oportuniza a criação de espaços 
públicos nos quais a ação comunicativa pode ser exercitada, bem como a autorreflexão dos sujeitos e do grupo. A pesquisa torna-se assim um espaço de conhecimento e autoconhecimento e ao mesmo tempo um espaço de crítica, que favorece a exploração da própria subjetividade, bem como as trocas intersubjetivas.

Acreditamos que, para aprimorar a proposta, ainda é necessário aprofundar alguns aspectos da epistemologia habermasiana, bem como detalhes a respeito dos métodos abordados, principalmente a socioanálise, pois esta envolve a psicanálise freudiana, que implica um estudo mais cuidadoso da técnica psicanalítica aplicada aos grupos. De qualquer forma, introduzimos a discussão e esperamos que esta possa ser produtiva e trazer novas possibilidades para a pesquisa no campo dos estudos organizacionais.

\section{Referências}

ADORNO, T. W. Introdução à Controvérsia sobre o Positivismo na Sociologia Alemã. In: ADORNO, T. W. Textos Escolhidos. Coleção “Os Pensadores”. São Paulo: Nova Cultural, 1974/1999. 117-161 p.

. et al. (Eds.). The Authoritarian Personality. New York: W. W. Norton \& Company, 1950/1993. 506 p.

ALTOÉ, S. Histórias de Interseção entre Psicoterapia Institucional e Análise Institucional. In: ALTOÉ, S. (Org.) Saúde e Loucura. Análise Institucional. São Paulo: Hucitec, 2004. p. 39-64.

ASSOUN, P. L. Introdução à Epistemologia Freudiana. Rio de Janeiro: Imago, 1983.

BARBIER, R. A Pesquisa-Ação. Brasília: Liber Livro, 1996/2007.

DOSSE, F. O Império do Sentido. A Humanização das Ciências Humanas. Bauru: EdUSC, 2003.

FREUD, S. Minhas Teses sobre o Papel da Sexualidade na Etiologia das Neuroses. In: FREUD, S. Edição Standard Brasileira das Obras Psicológicas Completas de Sigmund Freud. v. 7. Rio de Janeiro: Imago, 1905-1906/1996. p. 255-265.

. Psicologia de Grupo e Análise do Ego. In: FREUD, S. Edição Standard Brasileira das Obras Psicológicas Completas de Sigmund Freud. v. 18. Rio de Janeiro: Imago, 1921/1996. p. 79-154.

A Dissolução do Complexo de Édipo. In: FREUD, S. Edição Standard Brasileira das Obras Psicológicas Completas de Sigmund Freud. v. 19. Rio de Janeiro: Imago, 1924/1996. p. 191-199.

. O Mal-Estar na Civilização. In: FREUD, S. Edição Standard Brasileira das Obras Psicológicas Completas de Sigmund Freud. v. 21. Rio de Janeiro: Imago, 1929-1930/1996. p. 13-63.

Análise Terminável e Interminável. In: FREUD, S. Edição Standard Brasileira das Obras Psicológicas Completas de Sigmund Freud. v. 23. Rio de Janeiro: Imago, 1937/1996. p. 225-270.

Esboço de Psicanálise. In: FREUD, S. Edição Standard Brasileira das Obras Psicológicas Completas de Sigmund Freud. v. 23. Rio de Janeiro: Imago, 1938/1996. p. 153-221.

HABERMAS, J. Conhecimento e Interesse. Rio de Janeiro, Zahar, 1968/1982.

. Teoría de La Acción Comunicativa. Tomo I e Tomo II - Volumen Único. Madrid: Trotta, 1981/2010.

HILL, M. R. Epistemology, Axiology, and Ideology in Sociology. Mid-American Review of Sociology, v. 9, n. 2, p. 59-77, 1984.

HORKHEIMER, M. Teoria Tradicional e Teoria Crítica. In: BENJAMIN, W.; HORKHEIMER, M.; ADORNO, T. W. Textos Escolhidos. Coleção “Os Pensadores”. São Paulo: Abril Cultural, 1937/1980. 117-154 p. 
JAPIASSU, H. Psicanálise. Ciência ou Contraciência? Rio de Janeiro: Imago, 1998.

LAPASSADE, G. Grupos, Organizações e Instituições. Rio de Janeiro: Francisco Alves, 1974/1977. ; LOURAU, R. Chaves da Sociologia. Rio de Janeiro: Civilização Brasileira, 1971/1972.

LOURAU, R. A Análise Institucional. Petrópolis: Vozes, 1970/1975.

LÖWY, M. As Aventuras de Karl Marx contra o Barão de Münchhausen. Marxismo e Positivismo na Sociologia do Conhecimento. 6. ed. São Paulo: Cortez, 1998.

MARCUSE, H. A Ideologia da Sociedade Industrial. O Homem Unidimensional. 4. ed. Rio de Janeiro: Zahar, $1964 / 1973$.

NASIO, J. D. A Técnica Analítica. In: NASIO, J. D. Como Trabalha um Psicanalista? Rio de Janeiro: Jorge Zahar, 1999. 7-29 p.

ROUANET, S. P. A Epistemologia Freudiana. Revista Tempo Brasileiro, n. 82, p. 27-80, jul. 1985.

Teoria Crítica e Psicanálise. Rio de Janeiro: Tempo Brasileiro, 2001.

THIOLLENT, M. Metodologia da Pesquisa-Ação. 18. ed. São Paulo: Cortez, 1985/2011.

Pesquisa-Ação nas Organizações. 2. ed. São Paulo: Atlas, 1997/2009. 